\title{
EVALUASI PENERAPAN SISTEM INFORMASI AKUNTANSI PENJUALAN KREDIT PADA PT. JUMBO POWER INTERNATIONAL
}

\author{
Kintan Viktorina ${ }^{1}$, Harijanto Sabijono ${ }^{2}$, Sherly Pinatik ${ }^{2}$ \\ 1,2Jurusan Akuntansi, Fakultas Ekonomi dan Bisnis, Universitas Sam Ratulangi, Jl. Kampus Bahu, Manado, \\ 95115, Indonesia \\ ${ }^{1}$ E-mail : kintansalu@gmail.com
}

\begin{abstract}
Credit sales accounting information system involves several sections that handle the field of sales. Such as sales, credit, warehouse, shipping, billing and accounting. If every part does not work properly in accordance with the prevailing system, then it tends to make mistakes, both the sale and recording activities. This study aims to evaluate the application of credit sales accounting information systems at PT. Jumbo Power International is in accordance with the concept or not. The analytical method used in this thesis research is a descriptive method in which the purpose of each data collected is analyzed and drawn a conclusion. The research results obtained that the accounting information system for credit sales at PT. Jumbo Power International is in accordance with the concepts that form the basis of comparison, although there are still multiple tasks.
\end{abstract}

Keywords : credit sales; credit sales accounting information system

\section{PENDAHULUAN}

Di era industri sekarang ini banyak perusahaan baru yang bermunculan. Dengan adanya kemajuan dan kecanggihan teknologi, perusahaan dituntut untuk dapat bersaing di pangsa pasar untuk mempertahankan kelangsungan hidup dan menjadi perusahaan terbaik. Perusahaan adalah suatu bentuk badan usaha yang menjalankan kegiatan usahanya secara terus menerus dalam suatu wilayah dengan tujuan untuk mendapatkan laba atau keuntungan. Kegiatan utama yang harus dilakukan dan sebagai faktor penentu keberlangsungan hidup perusahaan adalah dengan melakukan penjualan. Penjualan dilakukan dengan dua cara yaitu, penjualan secara tunai dan penjualan kredit.

Penjualan tunai dilaksanakan oleh perusahaan, dengan cara mewajibkan pembeli melakukan pembayaran harga barang terlebih dahulu sebelum barang diserahkan oleh perusahaan kepada pembeli. Dalam melakukan penjualan kredit, tentunya perusahaan akan menimbulkan akun piutang dagang dalam laporan keuangan di neraca. Menurut Hery (2015:29), mendefinisikan istilah piutang adalah mengacu pada sejumlah tagihan yang akan diterima oleh perusahaan dari pihak lain, baik sebagai akibat penyerahan barang dan jasa secara kredit. Dalam menjalankan kegiatan penjualan secara tunai maupun kredit, tentunya perusahaan perlu untuk mengaplikasikan sistem informasi yang terstruktur. Sistem informasi akuntansi penjualan terdiri dari penjualan tunai dan kredit. Khusus dalam penelitian ini, peneliti berfokus pada sistem informasi akuntansi penjualan kredit.

Sistem informasi akuntansi penjualan kredit terdiri prosedur survei pelanggan, order penjualan, pengiriman barang, penagihan, dan pencatatan akuntansi melalui dokumendokumen yang digunakan, fungsi-fungsi yang terkait, catatan akuntansi yang digunakan dan prosedur yang terkait dengan penjualan kredit. Sistem informasi akuntansi penjualan kredit digunakan untuk mengendalikan aktivitas penjualan kredit dalam perusahaan Sistem informasi akuntansi penjualan melibatkan beberapa bagian yang menangani bidang penjualan. Seperti bagian penjualan, bagian kredit, bagian gudang, bagian pengiriman, bagian penagihan dan bagian akuntansi. Apabila setiap bagian tidak bekerja dengan baik sesuai 
dengan sistem yang berlaku, maka cenderung untuk terjadinya kesalahan, baik itu kegiatan penjualannya maupun pencatatannya.

Sistem informasi akuntansi penjualan pada PT. Jumbo Power International ditemukan kendala yaitu, masih ada fungsi yang terkait dengan penjualan kredit yang merangkap lebih dari satu pekerjaan. Dan adapun toko yang terkena musibah seperti kebakaran dan krisis keuangan toko sehingga terjadi pailit atau tidak mampu untuk membayar piutang sehingga memunculkan piutang tak tertagih. Untuk mengatasi permasalahan tersebut, tentunya dibutuhkan sistem dan prosedur yang jelas dan terstruktur agar proses penjualan kredit yang dilakukan dapat berjalan dengan baik dan pelaksanaan kegiatan penjualan kedepannya dapat dipertanggungjawabkan dengan benar. Tujuan dari penelitian ini adalah untuk mengevaluasi penerapan sistem informasi akuntansi penjualan kredit sudah sesuai dengan konsep atau belum.

\section{TINJAUAN PUSTAKA}

Akuntansi. Akuntansi ialah suatu sistem informasi keuangan, yang bertujuan untuk menghasilkan dan melaporkan informasi yang relevan bagi berbagai pihak yang berkepentingan (Kartikahadi et al., 2016:3). Akuntansi sebagai suatu aktivitas jasa yang terdiri dari mencatat, mengklasifikasikan, dan melaporkan kejadian atau transaksi ekonomi yang akhirnya akan menghasilkan suatu informasi keuangan yang akan dibutuhkan oleh pihak-pihak tertentu untuk pengambilan keputusan (Sujarweni, 2015:1).

Akuntansi Keuangan. Menurut Martani et al. (2012:8), akuntansi keuangan berorientasi pada pelaporan pihak eksternal. Bermacamnya pihak eksternal dengan tujuan mendetail bagi masing-masing pihak membuat pihak pembuat laporan keuangan menggunakan prinsip dan asumsi-asumsi dalam pembuatan laporan keuangan.

Sistem. Menurut Romney dan Steinbart (2015:3), sistem adalah rangkaian dari dua atau lebih komponen-komponen yang saling berhubungan, yang berinteraksi untuk mencapai suatu tujuan. Sebagian besar sistem terdiri dari subsistem yang lebih kecil yang mendukung sistem yang lebih besar.

Tujuan Sistem. Tujuan sistem merupakan target atau sasaran yang ingin dicapai oleh suatu sistem. Ciri-ciri atau kriteria dapat juga digunakan sebagai tolak ukur dalam menilai suatu keberhasilan suatu sistem dan menjadi dasar dilakukannya suatu pengendalian (Susanto, 2013:23).

Informasi. Menurut Hutahaean (2014:9), informasi adalah data yang diolah menjadi bentuk yang lebih berguna dan lebih berarti bagi penerimanya. Informasi merupakan data yang berguna bagi penerimanya dalam suatu organisasi maupun pihak luar organisasi baik dalam pengambilan keputusan atau manfaat lainnya.

Sistem Informasi Akuntansi. Menurut Krismiaji (2015:4), menyebutkan sistem informasi akuntansi adalah sebuah sistem yang memproses data dan transaksi guna menghasilkan informasi yang bermanfaat untuk merencanakan, mengendalikan, dan membuat keputusan.

Penjualan. Menurut Hery (2017:134), penjualan merupakan total jumlah yang dibebankan kepada pelanggan atas barang dagangan yang dijual perusahaan, baik meliputi penjualan tunai maupun penjualan secara kredit. Menurut Mulyadi (2013:202), penjualan adalah transaksi jual beli yang dilakukan penjual dan pembeli dengan cara pembayaran tunai maupun kredit.

Sistem Informasi Akuntansi Penjualan Kredit. Menurut Mulyadi (2016:160), dalam transaksi penjualan kredit, jika order dari pelanggan telah dipenuhi dengan pengiriman barang atau penyerahan jasa, untuk jangka waktu tertentu perusahaan memiliki piutang kepada pelanggannya. Kegiatan penjualan secara kredit ini ditangani oleh perusahaan melalui sistem penjualan kredit. Sistem informasi akuntansi penjualan kredit terdiri dari prosedur 
order penjualan, survei pelanggan, pengiriman barang, penagihan, dan pencatatan akuntansi melalui dokumen-dokumen yang digunakan, serta fungsi-fungsi yang terkait dengan penjualan kredit.

Peneliti Terdahulu. Kalumata (2017), tentang Evaluasi Pengendalian Internal Sistem Informasi Akuntansi Penjualan Dan Penerimaan Kas Pada PT. Hasjrat Abadi Cabang Malalayang Manado mendapatkan hasil Penerapan sistem dan prosedur akuntansi penjualan dan penerimaan kas yang dijalankan perusahaan telah cukup memadai dan terdapat struktur pengendalian internal yang baik.Tumalun (2019), tentang Analisis Sistem Informasi Akuntansi Penjualan Kredit Pada PT. Nusantara Cabang Sakti Manado mendapatkan hasil Sistem informasi akuntansi penjualan kredit di PT Nusantara Sakti Cabang Manado masih belum baik. Dilihat dari beberapa fungsi yang belum sesuai standar. Baramuli (2014), tentang Evaluasi Penerapan Sistem Informasi Akuntansi Penjualan pada PT. Ciputra Internasional Manado mendapatkan hasil Penerapan sistem dan prosedur akuntansi penjualan yang dijalankan perusahaan telah cukup memadai dan terdapat struktur pengendalian intern yang baik. Rawung (2016), tentang Analisis Efektifitas Sistem Akuntansi Penjualan dan Penerimaan Kas Pada PT. Surya Wenang Manado mendapatkan hasil Perusahaan dalam melaksanakan sistem akuntansi telah menerapkan struktur organisasi, sistem otorisasi dan prosedur pencatatan, serta praktek yang sehat dalam melaksanakan tugas sudah memadai.

\section{METODE PENELITIAN}

Jenis dan sumber data

Jenis data yang digunakan dalam penelitian ini adalah data kualitatif . Data kualitatif perusahaan berupa hasil wawancara tentang sejarah perusahaan, visi dan misi perusahaan, struktur organisasi, job description, dan gambaran tentang sistem informasi akuntansi penjualan kredit yang terdiri dari prosedur, dokumen, catatan akuntansi yang digunakan dan fungsi yang terkait dengan sistem informasi akuntansi penjualan kredit. Sumber data yang digunakan oleh penulis dalam penelitian ini yaitu data primer. Dalam hal ini, penulis mengumpulkan data secara langsung menyangkut dengan sistem informasi akuntansi penjualan kredit di perusahaan pada bagian Finance Accounting Division PT. Jumbo Power International.

Metode analisis yang digunakan dalam penelitian ini menggunakan metode analisis deskriptif, yang menggambarkan, menjelaskan dan membandingkan data yang diperoleh dan dibutuhkan mengenai sistem informasi akuntansi penjualan kredit yang ada pada PT Jumbo

Power International dengan teori yang menjadi landasan penelitian. Penulis menganalisis data kualitatif dengan cara yaitu:

1. Mendapatkan gambaran umum tentang perusahaan PT. Jumbo Power International.

2. Memperoleh dan mengumpulkan data yang berkaitan dengan sistem informasi akuntansi penjualan kredit pada PT. Jumbo Power International.

3. Menganalisis data yang diperoleh tentang sistem informasi akuntansi penjualan kredit pada PT. Jumbo Power International.

4. Menarik kesimpulan dan memberikan saran dari hasil penelitian.

\section{HASIL PENELITIAN DAN PEMBAHASAN}

\subsection{Hasil penelitian}

Konsep Penjualan. Penjualan kredit di PT. Jumbo International melibatkan, salesman, admin piutang,admin penjualan, supervisor sales, branch manager, kepala gudang, supir atau helper dan admin gudang. PT. Jumbo Power International menjual barang kepada pelanggan yang sudah menjadi pelanggan tetap atau pelanggan lama yang pernah order barang sebelumnya secara kredit sesuai dengan kriteria limit credit atau batas umur piutang pelanggan yang ditentukan olek branch manager/ chief $F A$. Berdasarkan wawancara dari pak yanto selaku chief $F A$ yang memberikan otorisasi kredit adalah branch manager dan Chief $F A$. Chief $F A$, hanya bisa memberi otorisasi kredit untuk pelanggan yang ingin membeli 
secara kredit tapi pelunasannya tidak lebih dari 60 hari atau hanya dalam waktu 60 hari piutangnya. Jadi jika lebih dari 60 hari harus meminta otorisasi dari branch manager.

Flowchart Penjualan Kredit. Flowchart yang ada pada PT. Jumbo Power International dimulai dari proses order oli atau minyak rem sampai ke pelanggan.

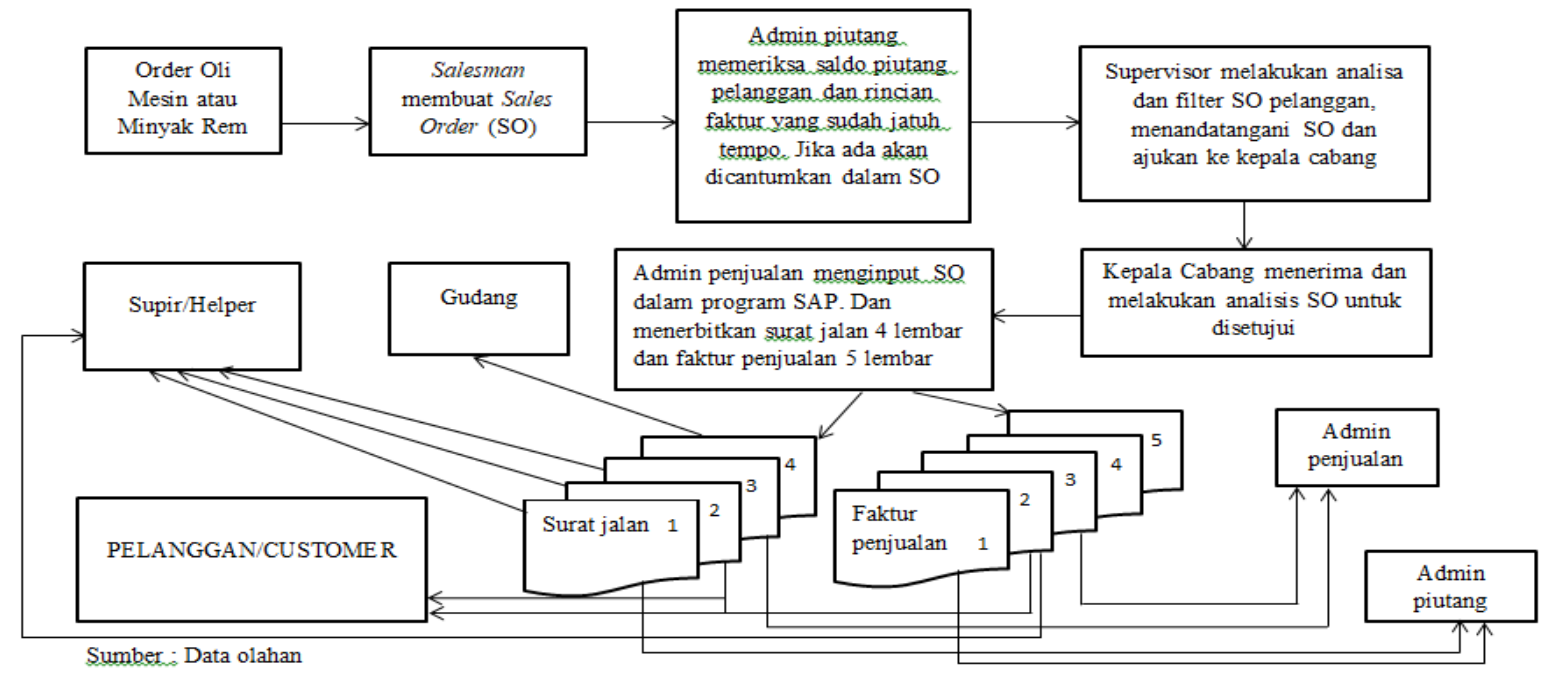

Sistem Informasi Akuntansi Penjualan Kredit. Sistem informasi akuntansi penjualan kredit pada PT. Jumbo Power International terdiri dari beberapa prosedur, fungsifungsi yang terkait dengan penjualan kredit, dokumen-dokumen yang digunakan dan catatancatatan akuntansi yang digunakan. Prosedur order penjualan kredit dimulai dengan membuat sales order ketika pelanggan melakukan pemesanan ditoko kepada salesman berupa oli mesin atau minyak rem apa saja, kemudian salesman langsung membuat SO (sales order) yang harus ditandatangani pelanggan dan dicap toko. Salesman menyerahkan SO untuk diserahkan ke bagian admin piutang untuk memeriksa jika masih ada saldo piutang sebelumnya, dalam hal ini apabila pelanggan atau toko yang membeli adalah pelanggan yang pernah membeli sebelumnya. Admin piutang akan mengecek saldo piutang pelanggan dan mencantumkan rincian faktur jika ada dan jika sudah jatuh tempo dalam sales order, untuk diberikan kepada supervisor sales dan dilakukan analisa atau filter SO pelanggan, serta menandatangani SO, setelah itu diajukan ke branch manager untuk melakukan analisa SO kembali untuk disetujui. Setelah disetujui oleh branch manager diserahkan ke bagian admin penjualan, untuk menginput SO dalam program SAP (System Application and Processing).Setelah itu admin penjualan mencetak surat jalan 4 rangkap dan faktur penjualan 5 rangkap dan harus ditandatangani oleh chief FA/Supervisor FA. Surat jalan dan faktur penjualan diberikan kepada kepala gudang untuk diperiksa jenis dan jumlah barang yang di order. Setalah diperiksa, bagian gudang bersama dengan supir dan helper menyiapkan barang yang diorder untuk dikirim sesuai dengan surat jalan dan menandatangani bersama. Kemudian melakukan muat barang ke kendaraan, sesuai wilayah (area) pengiriman barang.

Segera setelah pengiriman barang, admin gudang langsung melakukan pemotongan pada kartu stock sesuai jenis dan jumlah barang keluar pada surat jalan. Supir membawa faktur penjualan asli warna putih (lembar 1) dan copy merah (lembar 2) serta surat jalan asli warna putih (lembar 1), copy merah (lembar 2) dan copy kuning (lembar 3) karena surat copy biru (lembar 4) disimpan oleh kepala gudang untuk diarsipkan. Ketika barang diterima pelanggan, supir menyerahkan copy faktur penjualan warna merah (lembar 2) dan meminta tanda tangan, nama, stempel atau cap pelanggan pada surat jalan asli (lembar 1), copy merah ( lembar 2) dan copy kuning (lembar 3), kemudian menyerahkan surat jalan copy merah (lembar ke 2) ke pelanggan. Kemudian kepala gudang memeriksa surat jalan asli (lembar 1) dan copy kuning (lembar 3), apakah sudah ditandatangani, diberi nama dan stempel 
pelanggan, serta apakah ada sisa muatan dalam kendaraan. Kepala gudang menyerahkan kepada admin penjualan dan setelah itu menyerahkan faktur penjualan asli (lembar 1) dan surat jalan asli (lembar 1) ke admin piutang sebagai piutang menggunakan buku tanda terima dan surat jalan copy kuning (lembar 3) disimpan admin penjualan sebagai arsip accounting.

\subsection{Pembahasan}

\section{Fungsi-Fungsi yang terkait dengan penjualan kredit.}

1. Fungsi penjualan. Dalam transaksi penjualan kredit pada perusahaan, fungsi penjualan di tangani oleh salesman, supervisor sales dan admin penjualan. salesman membuat sales order, supervisor sales menganalisa, menandatangani dan filter sales order, admin penjualan menginput sales order dan mencetak surat jalan beserta faktur penjualan. Hal ini sudah sesuai dengan konsep yang dinyatakan oleh Mulyadi.

2. Fungsi Kredit. Fungsi kredit ditangani oleh chief FA dan branch manager. Chief FA memberikan otorisasi umur piutang (limit credit) untuk pelanggan yang pembayarannya tidak lebih dari 60 hari. Branch manager memberikan otorisasi kredit lebih dari 60 hari. Chief FA dan branch manager juga meneliti status kredit pelanggan. Hal ini sudah sesuai dengan konsep yang dinyatakan oleh Mulyadi.

3. Fungsi Gudang. Fungsi gudang ditangani oleh admin gudang dan kepala gudang. Kepala gudang menjaga supaya barang jangan sampai tertukar, karena jika tertukar resikonya terhadap konsumen, dan menjaga kerapian dalam gudang. Admin gudang menyarahkan surat jalan yang dicetak oleh admin penjualan kepada kepala gudang untuk diperiksa barang yang akan keluar dari gudang dan akan diberikan kepada supir dan helper. Hal ini sudah sesuai dengan konsep yang dinyatakan oleh Mulyadi.

4. Fungsi Pengiriman. Fungsi pengiriman ditangani oleh supir dan helper. Ketika kepala gudang selesai mengecek barang di surat jalan, supir dan helper langsung mempersiapkan barang yang akan dikirim sesuai dengan jenis dan jumlah barang pada surat jalan dan melakukan muat barang ke kendaraan, sesuai dengan wilayah (area) pengiriman barang. Hal ini sudah sesuai dengan konsep yang dinyatakan oleh Mulyadi.

5. Fungsi penagihan. Fungsi penagihan diperusahaan ditangani oleh admin piutang, salesman dan supervisor sales. Salesman melakukan penagihan ke pelanggan dengan membawa daftar tagihan yang dibuat oleh admin piutang yang sudah sesuai dengan faktur penjualan dan surat jalan. Hal ini sudah sesuai dengan konsep yang dinyatakan oleh Mulyadi.

6. Fungsi akuntansi. Ditangani oleh chief FA dan supervisor FA. Dalam perusahaan fungsi ini bertugas untuk mengontrol semua bagian yang berkaitan dengan laporan penjualan kredit dari pencatatannya, sampai dokumennya dalam sistem komputer. Hal ini sudah sesuai dengan konsep yang dinyatakan oleh Mulyadi.

\section{Dokumen-dokumen yang digunakan}

1. Surat Order Pengiriman. Pada PT. Jumbo Power International, dokumen yang digunakan adalah surat jalan yang digabung dengan faktur penjualan yang dikeluarkan oleh admin penjualan. Hal ini sudah sesuai dengan konsep yang dinyatakan oleh Mulyadi.

2. Faktur Penjualan Kredit. Pada PT. Jumbo Power Inertnational, faktur penjualan kredit dibuat oleh admin penjualan. Hal ini sudah sesuai dengan konsep yang dinyatakan oleh Mulyadi.

3. Rekapitulasi Harga Pokok Penjualan. Total harga pokok penjualan langsung diinput di sistem komputer. Hal ini sudah sesuai dengan konsep yang dinyatakan oleh Mulyadi.

4. Bukti Memorial. Pencatatan hanya berdasarkan dokumen faktur penjualan dan cek/ Bilyet Giro. Hal ini belum sesuai dengan konsep yang dinyatakan oleh Mulyadi.

\section{Catatan-catatan akuntansi yang digunakan}

1. Jurnal Penjualan. Jurnal penjualan langsung tersistem di komputer. Dengan akun piutang dagang dan harga pokok penjualan di debit kemudian akun penjualan, PPN keluaran dan persediaan barang jadi di kredit. Hal ini sudah sesuai dengan konsep yang dinyatakan oleh 
Mulyadi.

2. Kartu piutang langsung tersistem di komputer dan akan dibuatkan daftar tagihan. Hal ini sudah sesuai dengan konsep yang dinyatakan oleh Mulyadi.

3. Kartu Persediaan. Kartu persediaan langsung tersistem dikomputer, dengan yang berisi rincian mutasi persediaan. Hal ini sudah sesuai dengan konsep yang dinyatakan oleh Mulyadi.

4. Kartu Gudang. Kartu gudang digunakan untuk mencatat jumlah barang masuk dan keluar serta pada saat stock opname. Hal ini sudah sesuai dengan konsep yang dinyatakan oleh Mulyadi.

5. Jurnal Umum. Semua langsung tercatat dalam sistem komputer sesuai dengan dokumen yang terkait. Hal ini sudah sesuai dengan konsep yang dinyatakan oleh Mulyadi.

\section{KESIMPULAN DAN SARAN}

\subsection{Kesimpulan}

Berdasarkan hasil penelitian dan pembahasan tentang sistem informasi akuntansi penjualan kredit pada PT. Jumbo Power International dapat disimpulkan sebagai berikut : Penerapan sistem informasi akuntansi penjualan kredit pada PT. Jumbo Power International telah dilaksanakan sesuai dengan konsep-konsep yang dikemukakan oleh Mulyadi. Dari prosedur order penjualan sampai pada prosedur penagihan piutang yang melibatkan fungsifungsi yang terkait, dokumen-dokumen yang digunakan, dan catatan-catatan akuntansi yang digunakan. Meskipun ada beberapa dokumen dan catatan akuntansi yang belum sesuai serta terjadi perangkapan tugas antara beberapa fungsi. Salesman difungsi penjualan merangkap tugas difungsi penagihan. Dan chief $F A$ yang mengontrol semua bagian akuntansi yang berkaitan dengan penjualan kredit dari pencatatan sampai dokumennya juga merangkap tugas menangani fungsi otoritas pemberian kredit.

\subsection{Saran}

Berdasarkan penelitian, penulis memberikan saran yaitu salesman pada fungsi penjualan sebaiknya dipisahkan dari fungsi penagihan begitu juga dengan chief $F A$ yang menangani fungsi akuntansi lebih baik dipisahkan dengan fungsi pemberi orotitas kredit. Agar kinerja dapat berjalan secara efektif tanpa adanya perangkapan tugas yang terjadi.

\section{DAFTAR PUSTAKA}

Baramuli, J. \& Karamoy, H. (2014). Evaluasi penerapan sistem informasi akuntansi penjualan pada PT. Ciputra Internasional Manado. Jurnal Accountability, 3(1), 23-31.

https://doi.org/10.32400/ja.4938.3.1.2014.23-31

Hery. (2015). Analisis laporan keuangan, Edisi pertama. Yogyakarta: Center For Academic Publishing Services.

Hery. (2017). Teori akuntansi pendekatan konsep dan analisis. Jakarta: Grasindo.

Hutahaean, J. (2014). Konsep sistem informasi, Edisi pertama, Cetakan pertama. Yogyakarta: Deepublish.

Kartikahadi, H., Sinaga, U. S., Syamsul, M., Siregar, V. S., \& Wahyuni, T. E. (2016). Akuntansi keuangan berdasarkan SAK berbasis IFRS, Edisi kedua, Buku pertama. Jakarta: Salemba Empat.

Kalumata, N., Nangoi, G. B., \& Lambey, R. (2017). Evaluasi pengendalian internal sistem informasi akuntansi penjualan dan penerimaan kas pada PT. Hasjrat abadi cabang malalayang manado. Going Concern : Jurnal Riset Akuntansi, 12(2), 1-11. https://doi.org/10.32400/gc.12.2.18650.2017 
Krismiaji. (2015), Sistem informasi akuntansi, Edisi keempat. Yogyakarta : UPP STIM YKPN.

Martani, D. Sylvia, V. N., Wardhani, R., Farahmita, A., \& Tanujaya, E. (2012). Akuntansi keuangan menengah berbasis PSAK, Buku pertama. Jakarta: Salemba Empat.

Mulyadi. (2013). Sistem akuntansi, Edisi ketiga. Jakarta: Salemba Empat.

Mulyadi. (2016). Sistem akuntansi, Edisi keempat. Jakarta : Salemba Empat.

Rawung, F. R. (2016). Analisis efektivitas sistem akuntansi penjualan dan penerimaan kas pada PT. Surya wenang indah manado. Jurnal Berkala Ilmiah Efisiensi, 16(1), 705-805. https://ejournal.unsrat.ac.id/index.php/jbie/article/viewFile/11864/11453

Romney, M. B., \& Steinbart, P. J. (2015). Sistem informasi akuntansi, Edisi 13. Jakarta: Salemba Empat.

Sujarweni, V. W. (2015). Sistem akuntansi, Cetakan pertama. Yogyakarta: Pustaka Baru Press.

Susanto, A. (2013). Sistem Informasi Akuntansi. Bandung: Lingga Jaya

Tumalun, T. L. H., \& Pangerapan, S. (2019). Analisis sistem informasi akuntansi penjualan kredit di PT. Nusantara sakti cabang manado. Jurnal EMBA: Jurnal Riset Ekonomi, Manajemen, Bisnis dan Akuntansi, 7(3), 3019-3028.

https://ejournal.unsrat.ac.id/index.php/emba/article/view/24053 